\title{
Analýza aktuálních kompetencí žáků a studentů v určování našich obratlovců
}

\section{Jan Andreska a Kateřina Švecová}

Envigogika 9 (2) - Recenzované články/ Reviewed Papers

Publikováno/Published 31. 10. 2014

DOI: $\underline{10.14712 / 18023061.454}$

\section{Abstrakt}

Tato studie se zabývá výzkumem praktických znalostí žáků základních a středních škol. Je zaměřená na poznávání našich běžných druhư obratlovců (ryb, obojživelníků, plazů, ptáků a savců). Navazuje na výzkum (Lang, Pravda, 1971). Přebírá z velké části jejich metodiku a porovnává výsledky u vybraných referenčních druhů. Výsledky jsou zpracovány formou grafư a tabulek.

\section{Klíčová slova:}

Obratlovci; určovaní; výuka zoologie.

\section{Abstract}

This study focuses on research into the practical knowledge of primary and secondary school students. It is aimed at exploring common species of vertebrates (fish, amphibians, reptiles, birds and mammals) in the Czech Republic. It builds on research by Lang and Pravda, 1971. It takes a large part of their methodology and compares the results with selected reference species. The results are presented in graphs and tables.

\section{Key words:}

Vertebrates; determining; teaching zoology. 


\section{Úvod}

Převážná většina druhů obratlovců žijících volně v České republice je uvedena v Seznamu ohrožených zviŕat, známějším jako Červená kniha, a je chráněna více platnými právními normami, především ale zákonem č. 114/1992 Sb., o ochraně prírody a krajiny, a podle jeho prováděcí vyhlášky č. 395/1992 Sb., obě ve znění pozdějších předpisů. Právě s ohledem na právní ochranu této skupiny živočichů by bylo nesporně žádoucí docílit alespoň určitou míru znalosti jednotlivých druhů u nejširších občanských vrstev.

Mezi odbornou a částečně i laickou veřejností dlouhodobě přetrvává mylný dojem, že obratlovce do jisté míry každý samozřejmě zná, a jejich výuce tedy není nutné věnovat přehnanou pozornost (Andreska, 2005). Proto se stalo cílem této práce porovnání a zmapování skutečných biologických znalostí současných žáků ZŠ a SŠ v určování běžných druhů našich obratlovců (Švecová, 2013).

Cílem práce se stalo zkoumání dvou fenoménů, které jsme definovali následujícím způsobem: jednak jsme se soustředili na aktuální znalost př́rodnin, dále pak (a zejména) na komparaci výsledku našeho výzkumu s dostupnou prací, ve které bylo podobné zkoumání analogickým způsobem provedeno.

Počátkem sedmdesátých let dvacátého století se takovým zkoumáním zabýval kolektiv pod vedením autorů Jaroslava Langa a Oldřicha Pravdy na Pedagogických fakultách v Praze a v Českých Budějovicích. Své poznatky zveřejnili v publikaci „Problematika praktických znalostí biologických objektů žáků ZDŠ a SVVŠ" (Lang, Pravda, 1971).

\section{Metodika výzkumu}

Předchozí průzkum prováděli členové kolektivu Jaroslava Langa a Oldřicha Pravdy $\checkmark$ roce 1970 na velmi obsáhlém souboru respondentů (celkem jich bylo více než šest tisíc) v Praze, ve Středočeském kraji a v Jihočeském kraji. Prověřili takto celkem 22 škol, $z$ toho bylo 14 ZDŠ (základních devítiletých škol) a 8 SVVŠ (středních všeobecně vzdělávacích škol - gymnázií). Testovali poznávání různých organismů (rostlin a živočichů); jejich studie měla všeobecný charakter, obsahovala nejrůznější taxony z celého světa i vyšlechtěné odrůdy rostlin a rasy domácích zvírat. Tato jejich rozsáhlá práce měla především za úkol zjistit praktické vědomosti žáků $v$ biologii (botanice, zoologii a užité biologii) na základě předložených barevných diapozitivů. Snímky vycházely (dle slov autorů) z učebnic, běžně užívaných atlasů nebo príruček. Součástí studie (Lang, Pravda, 1971) však obrazová príloha nebyla, tudíž jsme museli přistoupit k vlastnímu výběru obrazového materiálu. (viz přiloha na konci článku) Jednalo se o barevné kresby na bílém či světlém pozadí, kde byl kladen důraz na zřetelnost determinačních znaků. Při vyhodnocování úrovně praktických vědomostí žáků se autoři obou studií soustředili na celkem čtyři kategorie odpovědí - znalost druhového jména, znalost rodového jména, záměnu a neznalost, jak je uvedeno $v$ tabulce č. 2 (viz dále).

Metodika použitá v této studii vycházela z původního výzkumu (Lang, Pravda, 1971) tak, aby bylo možné porovnávat výsledky. Tentokrát byl respondentům předložen obrazový materiál $v$ zatavené folii, přičemž balíček obsahoval vyobrazení 52 taxonů u nás žijících obratlovců ( 8 druhů ryb, 7 druhů obojživelníků a plazů, 21 druhů ptáků a 13 druhů savců). Tento poměr byl zvolen zcela záměrně a vycházel $z$ reálného zastoupení jednotlivých tříd obratlovců v ČR. Přehled testovaných druhů uvádí tabulka č. 1 (viz níže). V této tabulce jsou zeleně označené taxony, které byly zahrnuty i ve studii Langa a Pravdy (1971); ty se staly základem pro porovnání znalostí se současným výzkumem. Je nutné podotknout, že 
předmětem studie (Lang, Pravda, 1971) již žádné jiné druhy obratlovců vyskytujících se na našem území nebyly.

Protože $v$ původní studii nebyl publikován primární materiál, tedy fotografie nebo vyobrazení, podle kterých byly druhy určovány, zvolili současní autoři jako medium relativně jednoduchá vyobrazení, která ale obsahují podstatné diakritické znaky. Je samozřejmé, že materiál, podle kterého jsou druhy určovány, může ovlivnit výsledek, ovšem jednoznačné a $v$ obou př́padech stejné zadání testu toto riziko mělo snižit na minimum.

Tab. 1 Přehled testovaných taxonů

\begin{tabular}{|l|l|l|}
\hline sumec velký & volavka popelavá & vlaštovka obecná \\
\hline štika obecná & potápka roháč & jiričča obecná \\
\hline jeseter velký & straka obecná & pěnkava obecná \\
\hline okoun říční & sýkora koňadra & ježek západní \\
\hline lín obecný & brhlík lesní & bobr evropský \\
\hline cejn velký & kachna divoká & potkan \\
\hline úhoř říční & sojka obecná & křeček polní \\
\hline kapr obecný & hrdlička zahradní & veverka obecná \\
\hline zmije obecná & stehlík obecný & krtek obecný \\
\hline užovka obojková & koroptev polní & kuna skalní \\
\hline mlok skvrnitý & strakapoud velký & vydra říční \\
\hline ropucha obecná & datel černý & jezevec lesní \\
\hline rosnička zelená & puštík obecný & muflon \\
\hline ještěrka obecná & poštolka obecná & daněk skvrnitý \\
\hline slepýš křehký & dudek chocholatý & jelen lesnílevropský \\
\hline kos černý & lyska černá & prase divoké \\
\hline ledňáček říční & kavka obecná & \\
\hline kormorán velký & vrabec domácí & \\
\hline
\end{tabular}

Úkolem respondentů bylo zapsání rodového i druhového jména do očíslované tabulky. $\mathrm{K}$ objektivnímu posouzení znalosti objektu byly odpovědi následně rozčleněny do čtyř kategorií podle studie (Lang, Pravda, 1971), jak uvádí tabulka č. 2 (viz níže).

Tab. 2: Přehled kategorií odpovědí podle studie (Lang, Pravda, 1971) 


\begin{tabular}{|l|l|}
\hline Znalost druhu & $\begin{array}{l}\text { zařazeny plně správné odpovědi tj. znalost rodového i druhového } \\
\text { jména }\end{array}$ \\
\hline Znalost rodu & $\begin{array}{l}\text { odpovědi, kde byl správně zodpovězen pouze rod, druhové jméno bylo } \\
\text { bud' nesprávné, nebo chybělo úplně }\end{array}$ \\
\hline Záměna & $\begin{array}{l}\text { zahrnuje nesprávné odpovědi, kde bylo chybné i rodové pojmenování, } \\
\text { ale nejednalo se o odpovědi spadající do kategorie neznalost }\end{array}$ \\
\hline Neznalost & $\begin{array}{l}\text { obsahuje odpovědi nečitelné, zcela nesmyslné či dlužné (pokud } \\
\text { respondent neodpověděl vůbec). }\end{array}$ \\
\hline
\end{tabular}

Další částí výzkumu byl dotazník zjištující nejrůznější doplňující informace o respondentech. Obsahoval otázky týkající se předmětu přírodověda, přírodopis či biologie ve škole a zkoumal též volnočasové aktivity respondentů. Tento dotazník by měl poskytovat podklady pro budoucí hlubší rozbor problematiky faktorů ovlivňujících znalost jednotlivých druhů.

\section{Charakteristika testovaných skupin}

Výzkum probíhal ve školním roce 2011/2012. Skupinu respondentů ( $v$ celkovém počtu 298) tvořili žáci a žákyně základních a středních škol ze středních Čech a Prahy a dále členové př́rodovědného kroužku.

\section{Základiní škola Václava Havla, Revoluční 682, Kralupy nad Vltavou}

Základní škola Václava Havla se nachází v městské části Lobeček, leží v bytové zástavbě $v$ těsné blízkosti panelového sídliště. Školu navštěvuje cca 600 žáků. Má celkem 17 tříd $v 9$ ročnících. Pravidelně se zde otvírá od šestého ročníku třída s matematickoprírodovědným zaměřením s rozšířeným blokem prírodovědných předmětů. Díky vyššímu počtu hodin matematiky, fyziky a chemie jsou absolventi těchto tř́d lépe připraveni na přijímací zkoušky i další studium na kterémkoliv typu středních škol. Škola se pravidelně účastní mnoha matematických i prírodovědných soutěží. (Pythagoriáda, Matematikobiologická olympiáda, Př́rodovědný klokan a další).

Dotazníkové šetření na této škole proběhlo ve dvou souborech, ve dvou ročnících prvního stupně - ve čtvrtém ročníku (zde odpovídalo 22 respondentů) a pátém ročníku (32 respondentů).

\section{4. základní škola, Ukrajinská 2447, Kladno}

14. základní školu Kladno $v$ období, kdy probíhal výzkum, navštěvovalo 670 žáků. Měla 26 tříd pro 9 ročníků. Škola stojí na sídlišti v Kročehlavech, což je největší městská část. $V$ oblasti vzdělávání je tu věnována zvýšená péče žákưm $s$ vývojovými poruchami učení. Tito žáci jsou zařazeni $v$ běžných třídách a navíc pracují $v$ několika reedukačních skupinách pod dohledem odborníků. Z volnočasových aktivit probíhajících na zdejší škole a směřujících k oblasti př́rodovědy Ize jmenovat pěstitelský kroužek. 
$\mathrm{Na}$ této škole byly testovány dva soubory - soubor sedmých tříd (celkem 69 respondentů) a soubor deváté tř́dy (31 respondentů).

\section{Gymnázium Jana Palacha, Pod Vrchem 3421, Mělník}

Gymnázium Jana Palacha pro spádovou oblast Mělníka a jeho okolí má celkem 8 tříd čtyřletého a 8 tříd víceletého (osmiletého) gymnázia. To znamená celkem 12 tříd vyššího gymnázia a 4 třídy nižšího gymnázia poskytující všeobecné vzdělání. Odborná profilace studentů vyššího gymnázia je řešena systémem volitelných předmětů, které rozšiřují jejich znalosti jazykové, matematické, společenskovědní či přírodovědné (např. prrírodovědný seminář).

Také zde probíhal výzkum na dvou souborech respondentů - Gymnázium sekunda (25 respondentů) a Gymnázium septima (30 respondentů)

\section{SOŠ a SOU Čakovice, Ke stadionu 623, Praha 9}

Tato Střední odborná škola (SOŠ) a Střední odborné učiliště (SOU) má naprosto výjimečný maturitní obor Chovatel cizokrajných zviřat, o který je mimořádně velký zájem.

Žáci každý týden absolvují podle ročníku 6 až 14 hodin odborného výcviku v ZOO Praha, kde se učí zvládat veškeré činnosti týkající se péče o cizokrajná zviŕrata. Teoretická výuka ve škole je zaměřena na vysoce odborné předměty (chovatelství, krmivářství či základy veterinární péče o zviŕata) a jedním z profilových předmětů je samozřejmě biologie. Již při přijímacím pohovoru se předpokládá, že budoucí žáci a žákyně mají solidní přehled $v$ oblasti př́rodopisu, především se klade důraz na zoologii, a to nejen druhů exotických, ale též vyskytujících se $v$ naší prírodě. Během studia této střední školy se jejich zoologické vědomosti prohlubují a upevňují. Biologie je zde samozřejmě jedním z povinných maturitních předmětů.

Výzkum na této škole probíhal ve všech třech $v$ tomto školním roce otevřených ročnících, $v$ souboru SOŠ $-\mathrm{CH} 1$ odpovídalo 19 respondentů, 26 respondentů v souboru SOŠ - $\mathrm{CH} 2$ a v souboru SOŠ - $\mathrm{CH} 4$ celkem 19 respondentů.

\section{Př́rrodovědně - chovatelský kroužek ZOO Praha, U Trojského zámku 120/3}

Přestože z názvu by se dalo usuzovat, že prioritní náplní kroužků bude chovatelství, je $z$ velké části zaměřen na naši prírodu $z$ hlediska zoologického, botanického i ekologického. Lze říci, že tyto kroužky jsou určeny pro mladé a hloubavé děti s badatelskými sklony "durrellovského" typu od cca 5 let do 16 let, které mají opravdový zájem o přírodu. Členové př́rodovědně chovatelského kroužku jsou nejen z Prahy, ale mnozí dojiždějí do Tróji z okolních obcí (Neratovice, Kralupy nad Vltavou aj.).

Do výzkumu se zapojily děti ze všech věkových skupin. Celkem to bylo 25 respondentů, kteří byli posuzováni jako jeden soubor - Kroužky ZOO.

\section{Výsledky znalostí testovaných druhů}

Zde jsou uvedeny souhrnné grafy pro jednotlivé třídy živočichů ukazující obecnou znalost druhů, která byla testována na výše uvedených souborech. 


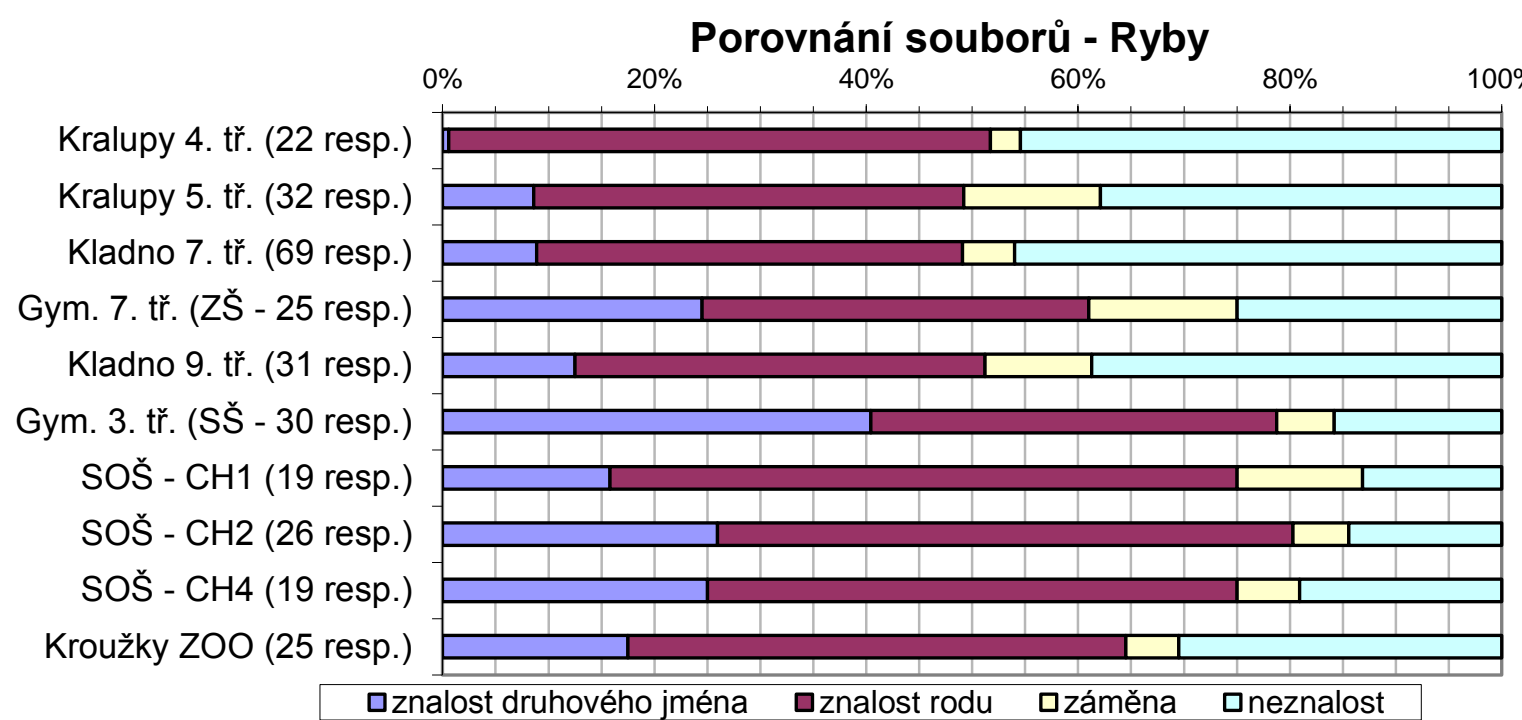

Graf 1 Porovnání výsledků znalostí testovaných taxonů tř́dy ryby u všech souborů respondentů studie (Švecová, 2013)

Mezi vybranými druhy $v$ dotazníku byly zastoupeny čtyři všeobecně známé taxony (sumec velký, štika obecná, úhoř říčni a kapr obecný). S jejich správným určením neměli respondenti $v$ žádném ze sledovaných souborů větší potiže. Další čtyři druhy byly správně determinovány s mnohem menší úspěšností; toto bylo zvláště patrné u souborů základních škol. $V$ souhrnném grafu pro třídu ryb se tyto výsledky kompenzují a výsledný průměr u souborů základních škol se tudiž pohybuje kolem $50 \%$. U souborů středních škol (Gymnázium septima a SOŠ) byla celková úspěšnost celkem vysoká; procento odpovědí, kde bylo správně určeno alespoň rodové jméno, se pohybovalo v rozmezí $75-80 \%$. $Z$ grafu je též patrné, že nejmladší děti (zvláště pak ty v souboru Kralupy 4. tř.) uváděly pouze rodová jména.

Je zřejmé, že obecná znalost ryb v naší zemi není na př́liš vysoké úrovni. S výjimkou těch nejznámějších několika málo druhů mají s jejich určováním problémy nejen děti základních a středních škol. Poznávat jednotlivé druhy nebývá snadné, nemá-li člověk $\mathrm{k}$ dispozici vhodnou príručku (Čihař, 1988). Biologické povědomí naší veřejnosti je ve srovnání s ekologicky vyspělými státy nižší a odráží se v něm naše ekologická krize (Povolný, 2011). Ryby jsou skutečně pro mnoho lidí neznámými živočichy. Pokud dítě nežije v rodině, kde se její členové věnují rybaření, má málo přiležitostí ryby ve volné prírodě pozorovat. Jednou z možností, jak Ize běžné druhy našich ryb vidět, jsou veřejnosti přístupné výlovy rybníků. Velmi poučná může být také např́klad návštěva expozice Česká řeka v Zoo Plzeň, některé druhy našich ryb Ize shlédnout i v ZOO Ohrada. Zajímavá je též stálá výstava Pod hladinou Vitavy na Staroměstském náměstí v Praze. Přes propagaci $v$ posledních letech (např. kampaň „Česká ryba") je u nás stále konzumace sladkovodních ryb velmi slabá. Městské dítě, které doprovází rodiče při nákupech v obchodních centrech, si může udělat dobrý obrázek o nejrůznějších exotických rybách - mořských i sladkovodních, ovšem našich původních druhů zde nalezne opravdu minimum. 


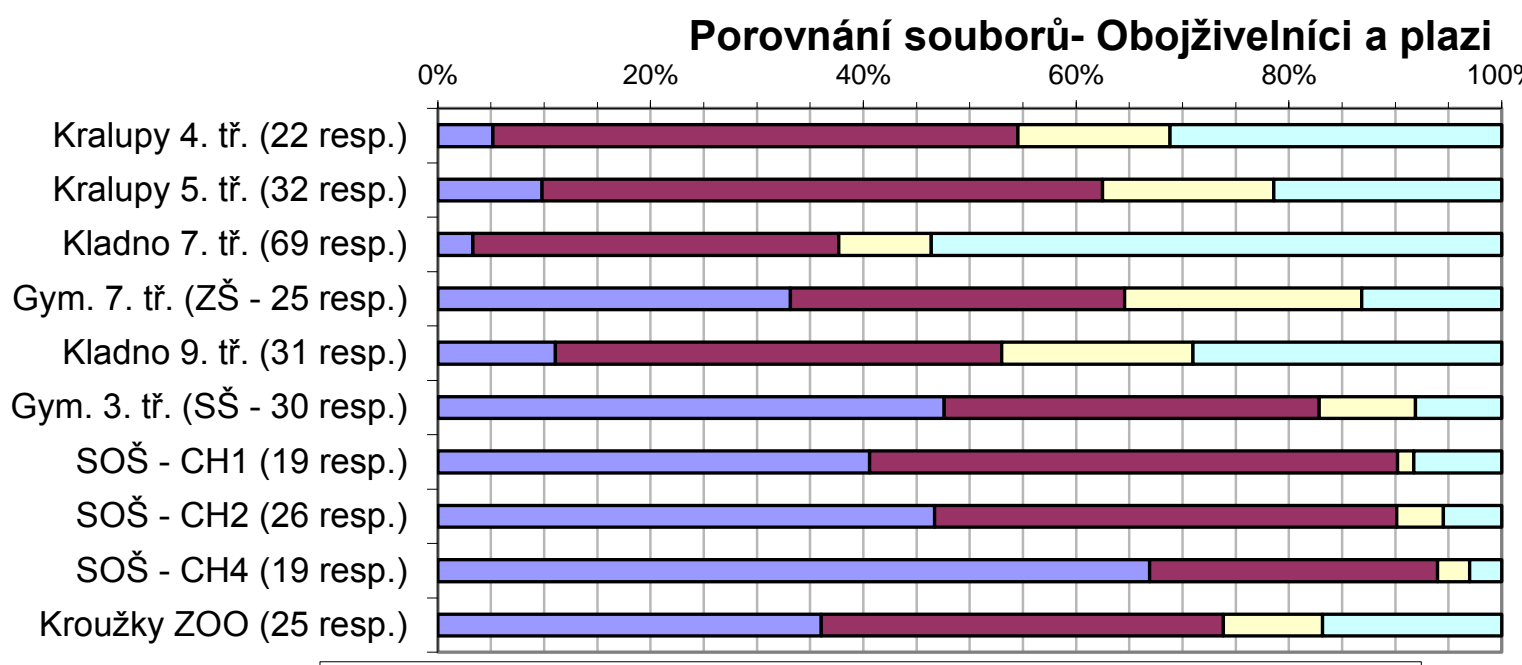

口znalost druhového jména $\quad$ aznalost rodu 口záměna $\quad$ aneznalost

Graf 2 Porovnání výsledků znalostí testovaných taxonů tř́i obojživelníci a plazi u všech souborü respondentů studie (Švecová, 2013)

Přestože do dotazníku byly zařazeny pouze ty nejznámější taxony (nejběžnější nebo $\mathrm{s}$ velmi výraznými určovacími znaky), mladší respondenti ze souborů základních škol byli v určování úspěšní pouze $v$ rozmezí $40-60 \%$. Z poznávaných druhů byla určována výrazněji lépe pouze ropucha obecná. Smutným zjištěním je, že naše dva nejznámější druhy plazů zmiji a užovku - velká část respondentů není schopna správně determinovat a docházelo $\mathrm{k}$ jejich častým záměnám mezi sebou. Bohužel právě jejich záměna $v$ prírodě může mít $\mathrm{i}$ neblahé následky. Soubory SOŠ měly úspěšnost přes $90 \%$, zde se takovýto výsledek dal celkem očekávat, protože mezi respondenty je mnoho teraristů.

$\checkmark$ lidech stále přetrvává nepříznivý názor na plazy jako na slizká stvoření, která jsou škodlivá a nebezpečná a je potřeba se jim zdaleka vyhnout - to $v$ lepším případě, $v$ horším případě je pak i zlikvidovat. Podobně je to také v prípadě obojživelníků. Postupná výchova veřejnosti $\mathrm{k}$ rozumnému př́stupu $\mathrm{k}$ plazům bez přehnaných zábran a středověkých předsudků, které se projevují nekulturním pronásledováním všech plazů a obojživelníků (Pecina, 1988), a další osvětová činnost je zde proto jistě na místě. Jednou z možností je pozorování prímo $v$ prírodě. Pro laiky jsou tyto skupiny obratlovců pro svou agilnost a plachost dosti obtí̌ně pozorovatelné, je třeba hodně trpělivosti a také dobrá znalost terénu. Proto je jednodušší navštívit některé chovatelské zařízení, zabývající se chovem našich obojživelníků a plazů. Např́íklad ZoO Ohrada či Plzeň mají pěknou ucelenou kolekci těchto živočichů. $\mathrm{S}$ dětmi se Ize angažovat i v aktivní ochraně. Je možné se zapojit do některých programů ČSOP. Další možností je úprava vhodného životního prostředí pro plazy či obojživelníky třeba na školním pozemku či někde v okolí. 


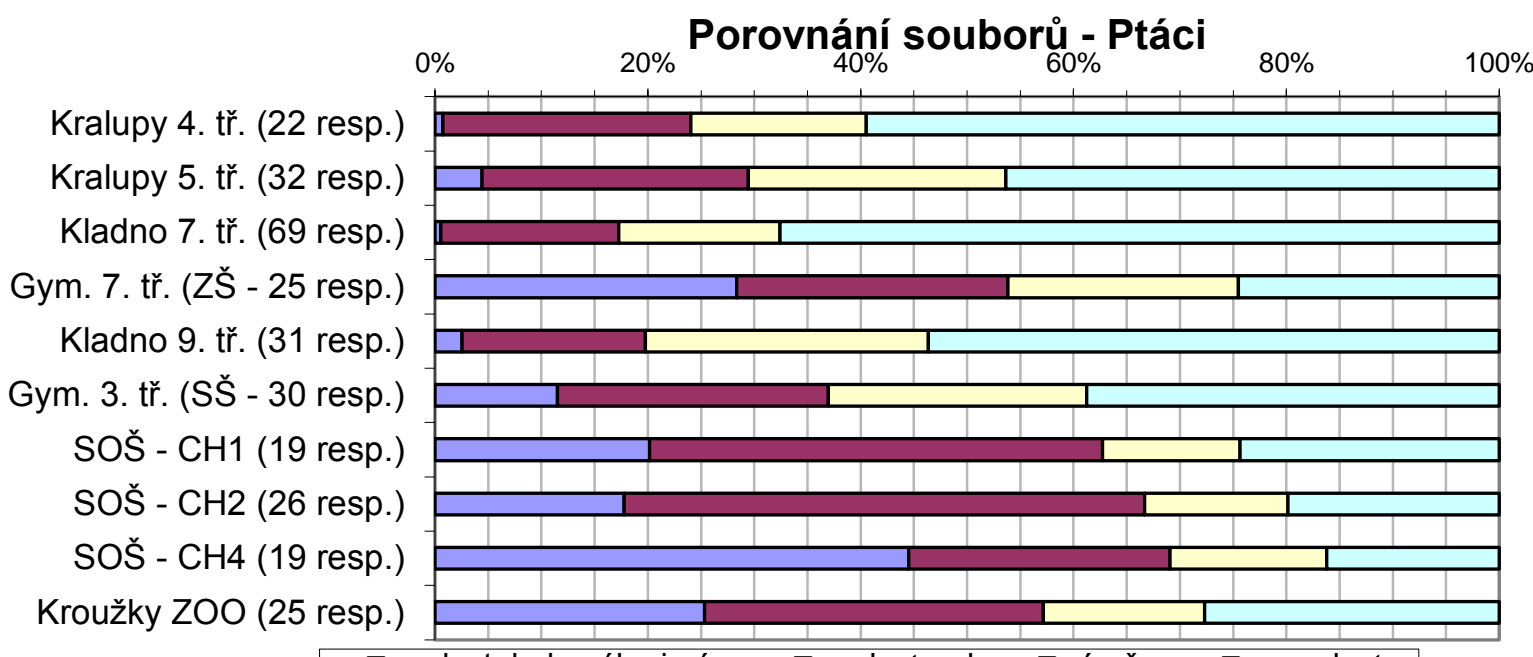

口znalost druhového jména aznalost rodu azáměna $\quad$ 口neznalost

Graf 3 Porovnání výsledků znalostí testovaných taxonů třídy ptáci u všech souborů respondentů studie (Švecová, 2013)

Při porovnávání výsledků určování jednotlivých tříd obratlovců, bylo jednoznačně patrné, že právě ptačí taxony dotazovaným činily největší potiže. $Z$ grafu Ize vyčíst, které soubory respondentů si vedly hůře než ostatní. Všechny soubory základních škol měly úspěšnost pouze $v$ rozmezí $15-30 \%$. Velmi špatných výsledků dosáhl $v$ této části také soubor Gymnázium septima, jeho průměrná úspěšnost byla jenom málo přes $35 \%$ v určení rodových jmen. Ani v souboru SOŠ - $\mathrm{CH} 4$, který v této části zaměřené na tř́du ptáci dosáhl nejlepšího výsledku, úspěšnost v určení alespoň rodových jmen nedosáhla 70\%.

Ze všech tříd obratlovců jsou ptáci druhově nejpestřejší a $v$ České republice $\mathrm{i}$ nejpočetnější. Se zástupci této třídy se Ize potkat téměř na každém kroku, vyskytují se ve všech biotopech existujících u nás. Jejich hlasové projevy jsou většinou nepřeslechnutelné, velice nápadné a druhově specifické. Znalost hlasových projevů (zpěvu, vábení, poplašného křiku atd.) je velmi cennou pomůckou při zjištování ptáků ve volné přírodě a jejich určování; u druhů s noční aktivitou anebo u těch, které žijí v hustě zarostlých, nepřehledných místech, může být dokonce jediným nebo hlavním způsobem jejich zjištění (Balát, 1986). Pokud do terénu půjdeme s odborným průvodcem, můžeme s jeho pomocí rozeznat desítky taxonů, které jinak unikají pozornosti laiků. Mnoho druhů Ize celkem snadno pozorovat dalekohledem, větši druhy i pouhým okem. Můžeme je ve městech přivábit na krmítka, pítka, či jim poskytnout hnízdní příležitosti. Přesto jsou ptáci u nás širší veřejností velmi opomíjenou skupinou, jsou to "jenom ptáci" - tento názor můžeme často slýchat například mezi návštěvníky v zOO. Je to dáno tím, že i přes dobrou tradici ornitologie v České republice je tento jistě zajímavý obor biologie velmi málo propagován. Proto jsme $v$ porovnání $\mathrm{s}$ některými evropskými státy stále pozadu. Příkladem nám budiž Královská společnost ornitologická ve Velké Británii, která má obrovskou členskou základnu mezi laickou veřejností a tudíž i její velkou podporu.

Také z výsledků této studie je patrné, že ani mezi nejmladší generací, do které patřili respondenti výzkumu, nedochází k posunu k lepšímu. Dokonce i soubory respondentů, u kterých by se dalo předpokládat, že $\mathrm{k}$ prrírodě mají blízko a budou tak mnohé druhy bezpečně znát, jmenovitě soubory SOŠ nebo zájmové kroužky, dosahovaly pouze průměrně dobrých výsledků. U některých naprosto běžných druhů, jako např. brhlík nebo pěnkava, byly 
výsledky naprosto tristní a hledání východiska z této situace by vydalo na několik dalších prací.

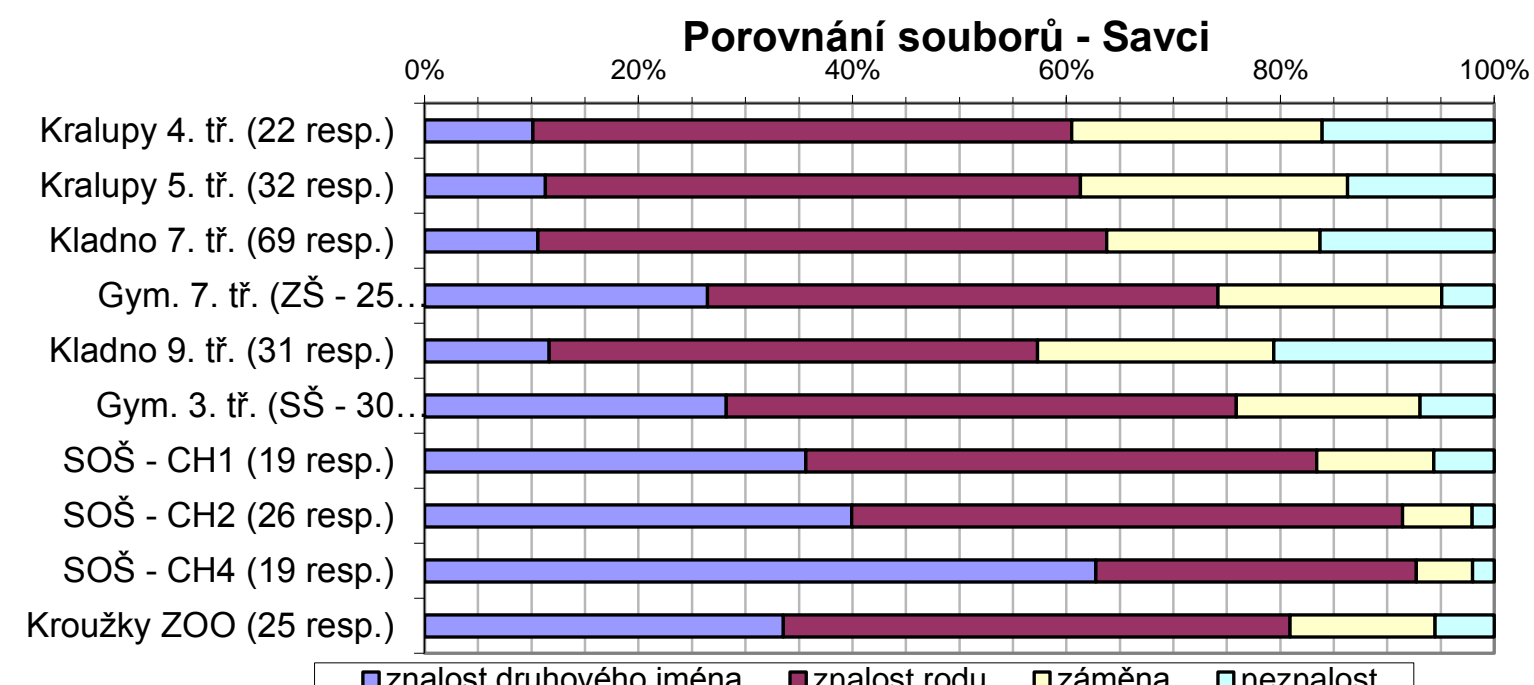

Graf 4 Porovnání výsledkü znalostí testovaných taxonů třídy savci u všech souborů respondentů studie (Švecová, 2013)

V určování savců měly všechny soubory dost vyrovnané výsledky. Nejlépe dopadly soubory SOŠ (úspěšnost v určování rodového jména 80-90\%), u těchto souborů byla také nejlepší znalost druhového pojmenování. Zvlášt́ dotazovaní v souboru SOŠ - $\mathrm{CH} 4$ uvedli úplné správné pojmenování i s druhovým označením u více jak $60 \%$ savců. Velice dobře si vedli i respondenti souborů Kroužky zoO a též oba soubory Gymnázia, zde se průměrná znalost rodu pohybovala $v$ rozmezí $75-80 \%$. Soubory základních škol měly úspěšnost pouze okolo $60 \%$.

Savci jsou vnímáni většinou lidí jako dobře známá skupina zviŕat. Výzkum jako tento však může pomoci odhalit, že tomu tak není ve všech př́padech, může pomoci odhalit takovýto průzkum. Do testu byly zahrnuty pouze druhy $s$ dobře rozpoznatelnými determinačními znaky nebo druhy naprosto běžné, které Ize celkem snadno pozorovat prímo ve volné přírodě. Některé druhy jsou hojné i ve městech, zahradách, parcích či v oborách. Savci jsou bezesporu velmi atraktivní součástí přírody, ale méně nápadní než např. ptáci, takže zájem o ně je sycen spíše z knih, filmů a televizních seriálů (Pelikán a kol., 1979). Většina našich savců žije tak skrytě, že o jejich existenci nemáme ani potuchy (Kholová, 1980). Výsledkem toho je, že dnes lidé u nás vědí mnohem více o savcích afrických savan, než o těch, kteří jim běhají v zahradě, kolem chalupy nebo v lese za chatou (Pelikán a kol., 1979). Existují ale možnosti, jak si prohlédnout i druhy s noční aktivitou nebo zviŕata velmi skrytě žijící - např. v zookoutcích, záchranných stanicích pro handicapovaná zviřata či v zoologických zahradách specializovaných na chovy evropských druhů (Zoopark Chomutov, zoO Ohrada, př́padně další). Moderní technologie (internet, rozhlas, televize) poskytují zprostředkovanou alternativu k prímému pozorování obratlovců a přírody obecně. Bohužel, $\checkmark$ naší televizi se dokumentů o evropské prrírodě mnoho nevyskytuje. Za velmi prínosné $v$ tomto směru Ize pokládat hrané večerníčky, které natočil se zvíraty Václav Chaloupek.

Možná, že právě kvůli zakořeněné představě, že u nás žijící savce zná každý, jsou tito veřejností opomíjeni - není přece potřeba se o nich učit. Přesto, a možná právě proto, mnohým respondentům činily některé taxony $z$ tř́dy savců při určování nemalé potíže. 
Výzkumem našich drobných savců se i česká oficiální věda začala soustavně zabývat až po druhé světové válce (Pelikán a kol., 1979).

\section{Srovnání výsledků referenčních druhů se studií Lang, Pravda}

Jedním z úkolů této studie bylo alespoň částečně porovnat výsledky s již provedenými výzkumy (Lang, Pravda, 1971). K tomu bylo vybráno do poznávací části celkem devět referenčních druhů, které jsou zeleně uvedeny v tabulce č. 1 (viz výše - kapitola Metodika výzkumu). Pro objektivní porovnání je třeba vybrat srovnatelné soubory. Jedním kritériem je oblast (kraj) kde byl výzkum prováděn. Vzhledem $\mathrm{k}$ souborům testovaným $v$ této studii byly pro srovnání vybrány výsledky studie Langa a Pravdy (1971) pro Prahu a Středočeský kraj. Hlavním kritériem je ale věk respondentů, který zásadně ovlivňuje jejich znalost druhů. Ten totiž může ovlivnit, zda byl taxon již probírán $v$ rámci školní výuky. Autoři současné studie jsou si vědomi, že mezi testovanými skupinami jsou též soubory, které se vymykají celorepublikovému průměru, jmenovitě se jedná o soubory SOŠ - Chovatel cizokrajných zviŕat; zde pak jediným srovnávacím kritériem zůstal stejný věk respondentů.

V grafech jsou proto seřazeny soubory do tzv. „věkových skupin" odlišených barevně. Vždy se jedná o jeden soubor ze studie (Lang, Pravda, 1971) - zde označovaný pouze zkratkou Lang + tř́́da (ročník) - a věkově odpovídající soubor či soubory testované v rámci současného výzkumu.

\section{Jeseter velký (Acipenser sturio)}

V porovnávaných souborech základních škol byly ve všech případech úspěšnější soubory "Lang", které měly v průměru o 10\% lepší výsledky než současné testované soubory. Opačná situace nastala u souborů středoškolských, kde respondenti souborů SOŠ i Gymnázia uspěli lépe, výraznější rozdíl byl zaznamenán především ve věkové skupině 2 . ročníku (rozdíl téměř $35 \%$ v určení rodu).

Ve všech sledovaných souborech byla velice nízká znalost druhového jména - tato kategorie se u většiny souborů vůbec v grafech nepromítla, pouze v souboru "Lang" 7 . tř. dosáhla kategorie znalost druhu $5 \%$, a dále v souboru Gymnázium septima, kde byla tato hodnota o něco nižší.

Z grafu vyplývá, že tento taxon činil při určování potíže respondentům současných souborů i souborů "Lang"; potvrzuje se tak celková nízká znalost tohoto druhu u nás. 


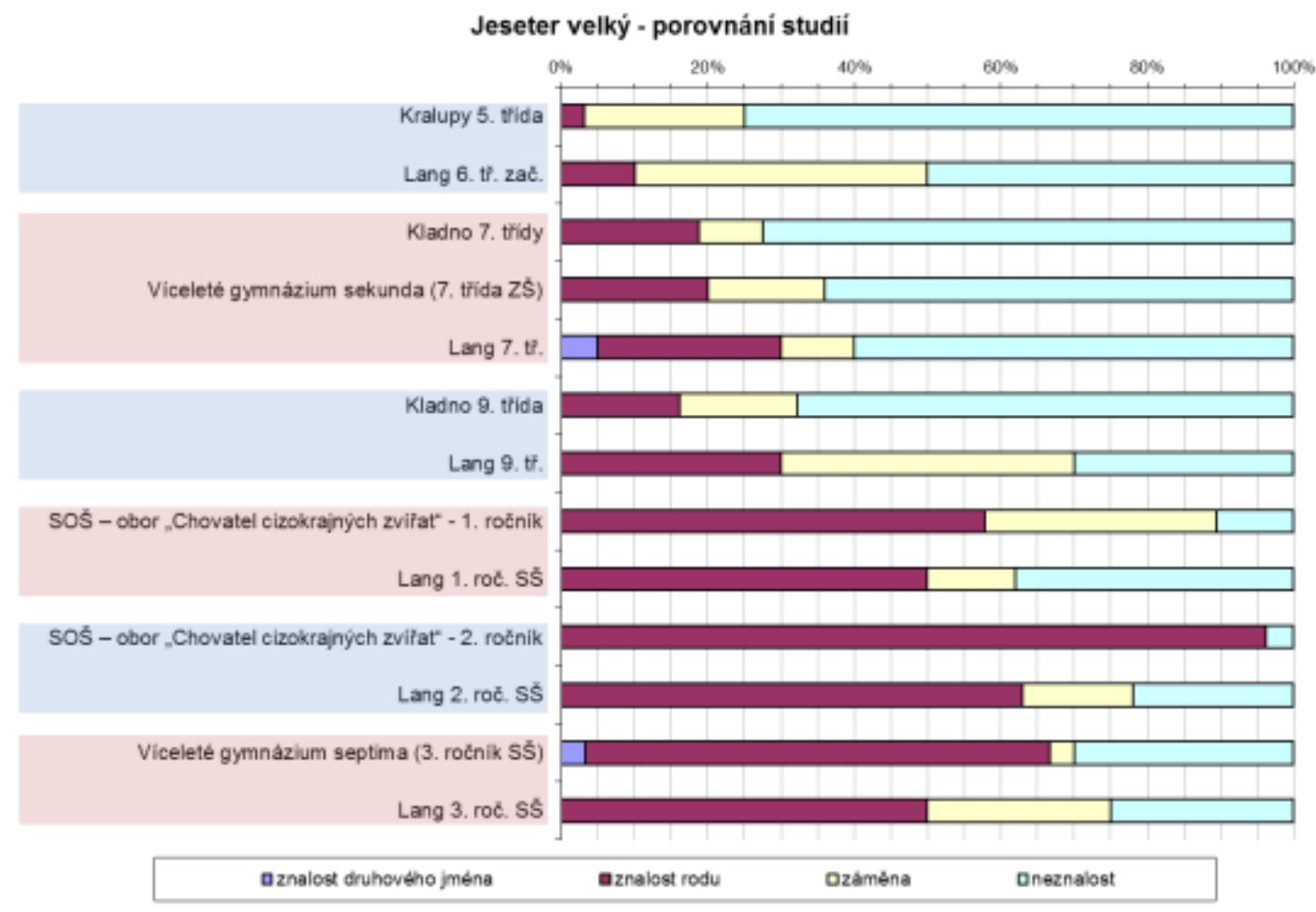

Graf 5 Porovnání znalosti druhu jeseter velký pro jednotlivé věkové skupiny respondentů studie (Švecová, 2013) a studie (Lang, Pravda, 1971) 


\section{Lín obecný (Tinca tinca)}

Z grafu je na první pohled ž̌ejmé, že tento taxon nečinil potíže pouze současným respondentům, také ve studii "Lang" nebyly výsledky nikterak výjimečně dobré. Ve srovnávaných souborech věkové skupiny 5 . tříd nepoznal lína nikdo. $V$ souborech věkových skupin 7. tříd a 9. tříd dosáhly mírně lepších výsledků soubory "Lang". Naopak na středních školách měly vyšší úspěšnost současné testované soubory. Výraznější rozdíl (přibližně 30\%) byl patrný ve srovnání souborů SOŠ - CH1 oproti "Lang" a podobných hodnot bylo dosaženo i ve srovnání souborů SOŠ - CH2 oproti "Lang". Respondenti souboru Gymnázium septima (odpovídající třetímu ročníku středních škol) byli nejvíce úspěšní ze všech sledovaných souborů (znalost rodu více než 55\% a zároveň vysoká znalost druhového pojmenování $40 \%)$.

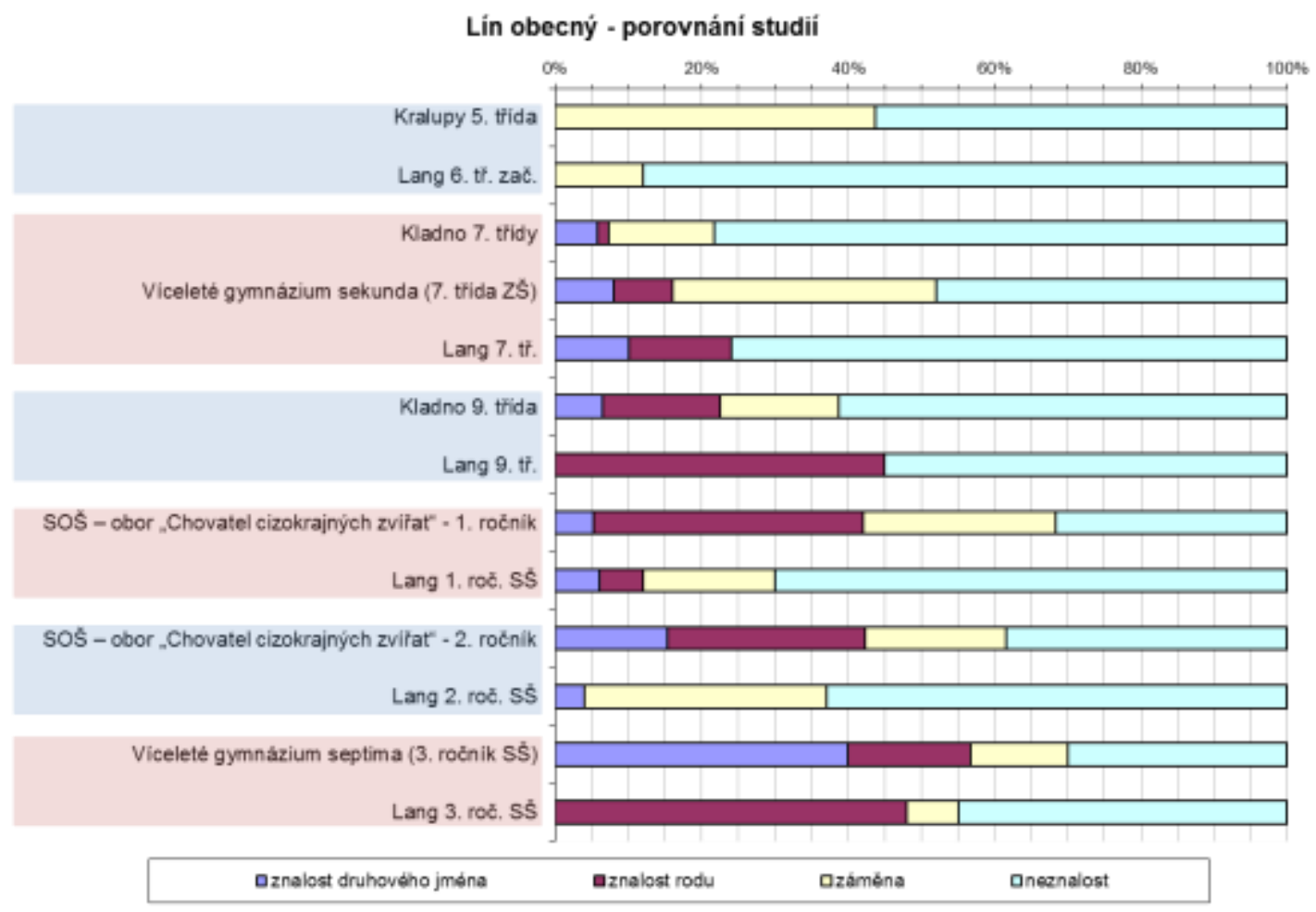

Graf 6 Porovnání znalosti druhu lín obecný pro jednotlivé věkové skupiny respondentů studie (Švecová, 2013) a studie (Lang, Pravda, 1971) 


\section{Cejn velký (Abramis brama)}

Znalost tohoto taxonu je ve všech porovnávaných souborech velice nízká. Znalost rodu se pohybuje $v$ rozmezí od $0 \%$ (soubor Kralupy 5. třída) do 45\% (soubor Gymnázium septima). Ve třech věkových skupinách byli úspěšnější respondenti souborů "Lang" (ve věkové skupině 5. tříd, 9. tříd a 1. ročníku SŠ), než současné testované soubory. Současné testované soubory byly úspěšnější též ve třech případech (věková skupina 7. tříd, 2. ročníku SŠ a 3. ročníku SŠ).

V žádném souboru "Lang" nikdo neznal celé jméno včetně druhového. Ve čtyřech současných testovaných souborech se objevily správné odpovědi v plném znění, v souborech Kladno 7. tř., Kladno 9. tř., SOŠ - CH2 a Gymnázium septima odpovědělo 5 až $15 \%$ respondentů, že se jedná o cejna velkého.

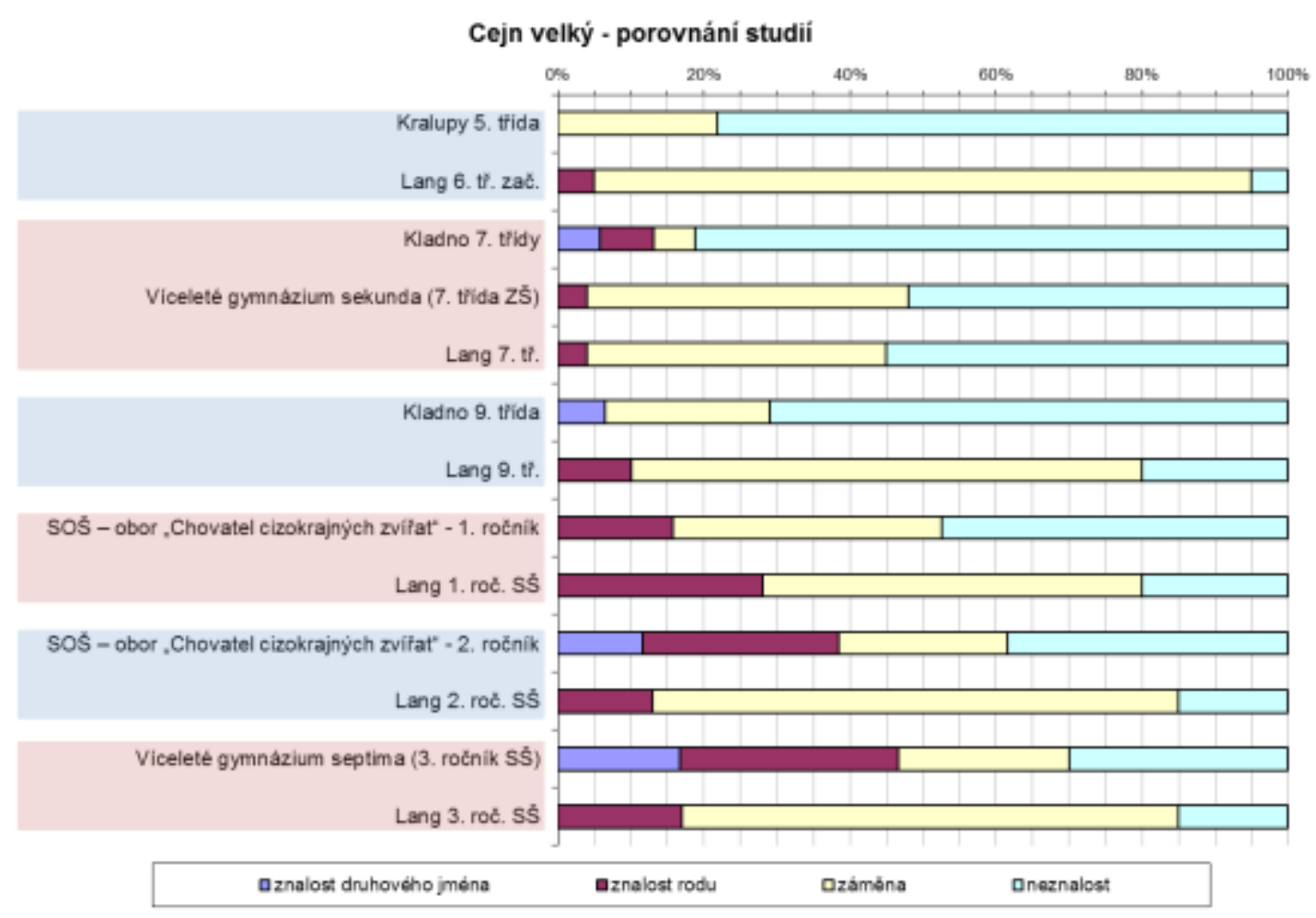

Graf 7 Porovnání znalosti druhu cejn velký pro jednotlivé věkové skupiny respondentů studie (Švecová, 2013) a studie (Lang, Pravda, 1971) 


\section{Okoun říční (Perca fluviatilis)}

Ze čtyř referenčních druhů ryb byl právě tento taxon určen nejúspěšněji. Alespoň rodové jméno určily lépe současné testované soubory $v$ pěti ze šesti věkových skupin. V rámci jedné věkové skupiny srovnávaných souborů byl největší rozdíl (celých 60\%) u 1. ročníku SŠ; zde soubor SOŠ - CH1 dosáhl úspěšnosti 95\%, kdežto soubor "Lang" pouze $35 \%$. Naopak nejvyrovnanější výsledek byl ve věkové skupině 5 . tříd, kde soubory "Lang" i Kralupy 5. tř. měly shodně $45 \%$ správných odpovědí v kategorii znalost rodu.

Také s určováním druhového jména se lépe vypořádaly současné testované soubory. U pěti souborů "Lang" se znalost druhového jména na grafu vůbec neprojevila.

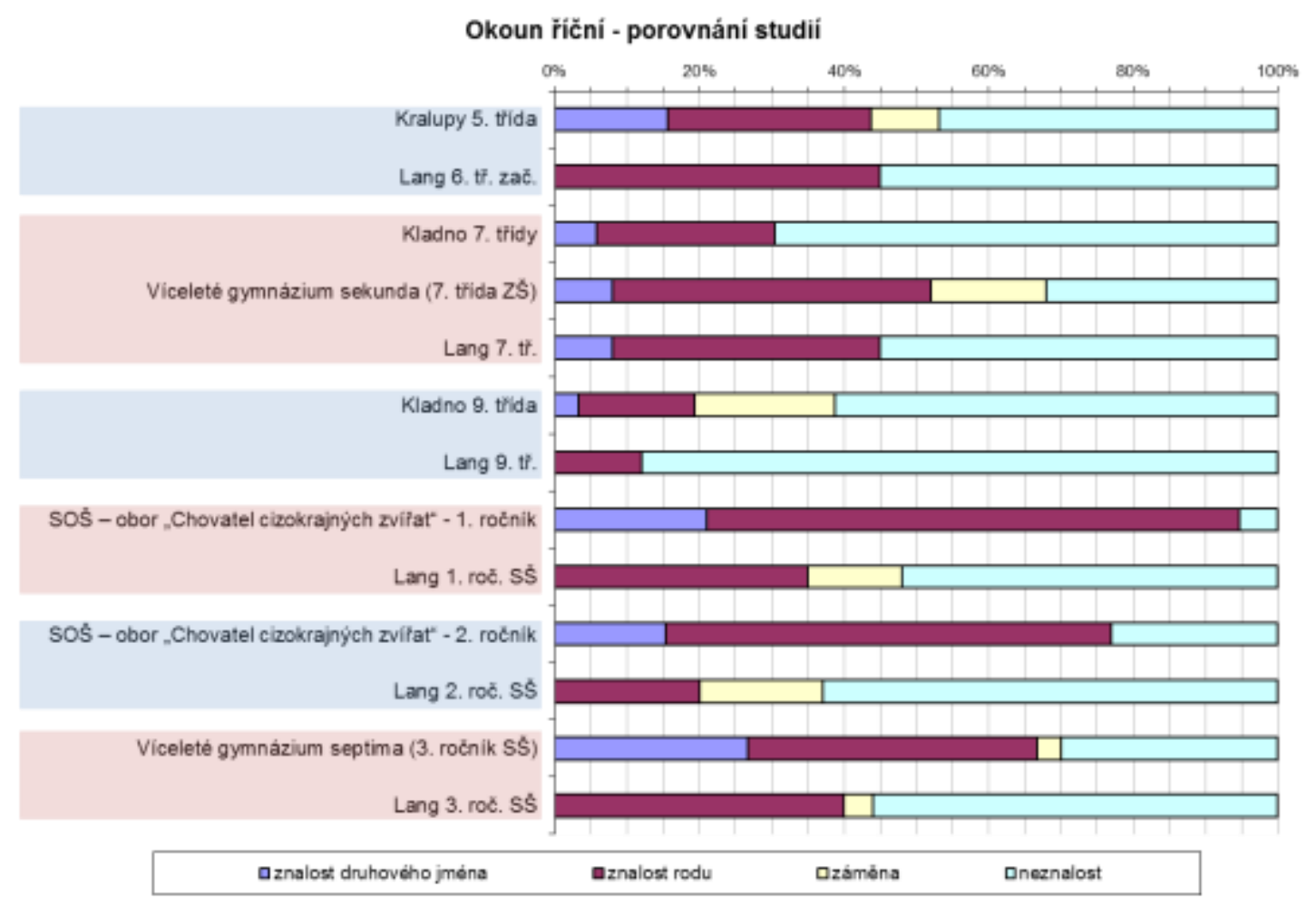

Graf 8 Porovnání znalosti druhu okoun říční pro jednotlivé věkové skupiny respondentů studie (Švecová, 2013) a studie (Lang, Pravda, 1971) 


\section{Ropucha obecná (Bufo bufo)}

Všechny sledované soubory měly $v$ určování tohoto obojživelníka poměrně dobré výsledky. Rodová znalost se ve všech souborech pohybovala nad $60 \%$, tři současné testované soubory (Gymnázium sekunda, Gymnázium septima a SOŠ - $\mathrm{CH} 2$ ) dosáhly plných $100 \%$. Ve věkové skupině 5 . tříd si s určením rodu lépe poradili respondenti souboru "Lang" (s rozdílem přibližně $10 \%$ ). Ve věkové skupině 9 . tříd byly výsledky obou souborů velice vyrovnané. Ve věkové skupině 7. tříd byl nejúspěšnější soubor Gymnázium sekunda, úspěšnost o 5\% nižší pak měl soubor "Lang" a nejhưře dopadl soubor Kladno 7. tř. Ve všech třech skupinách středoškolských souborů měli lepší výsledky respondenti současných testovaných souborů (v průměru o 25 - 30\%) než "Lang".

Druhová znalost byla ve všech porovnávaných skupinách vyšší u současných testovaných souborů. Nejlépe znali druhové jméno dotazovaní v souboru Gymnázium sekunda $(60 \%)$ a dobrých výsledků dosáhli i respondenti v souboru Gymnázium septima (přes 40\% plně správných odpovědí s uvedeným druhovým jménem).

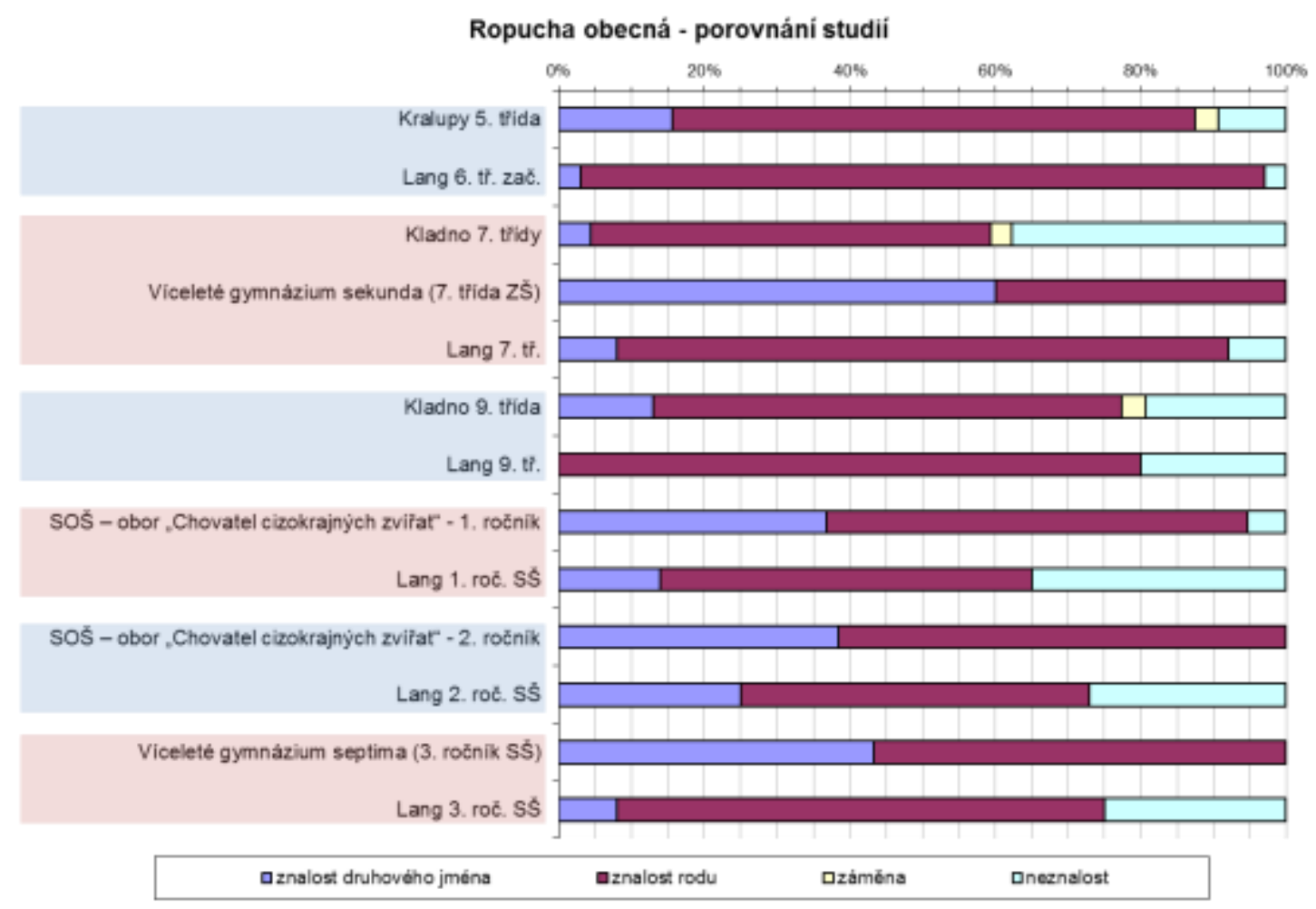

Graf 9 Porovnání znalosti druhu ropucha obecná pro jednotlivé věkové skupiny respondentů studie (Švecová, 2013) a studie (Lang, Pravda, 1971) 


\section{Poštolka obecná (Falco tinnunculus)}

Kromě věkové skupiny 2. ročníku SŠ, kde byl výsledek u obou souborů přibližně shodný, ve všech ostatních věkových skupinách úspěšněji ropuchu poznávali respondenti souborů "Lang". Nejvýraznější rozdíl byl zaznamenán ve věkové skupině 7. tříd, kde byl soubor "Lang" oproti zbývajícím dvěma současným testovaným souborům o $50 \%$ úspěšnější. Velký rozdíl byl též ve skupině 9. tříd, zde respondenti souboru "Lang" dosáhli ve svých odpovědích přibližně o $35 \%$ lepšího výsledku. Ve skupinách středních škol byly rozdíly ve znalostech již podstatně vyrovnanější.

Znalost druhového jména byla ve všech porovnávaných souborech nízká, pouze u dvou souborů dosáhla 20\% („Lang" 7. tř. a "Lang" 1.ročník SŠ).

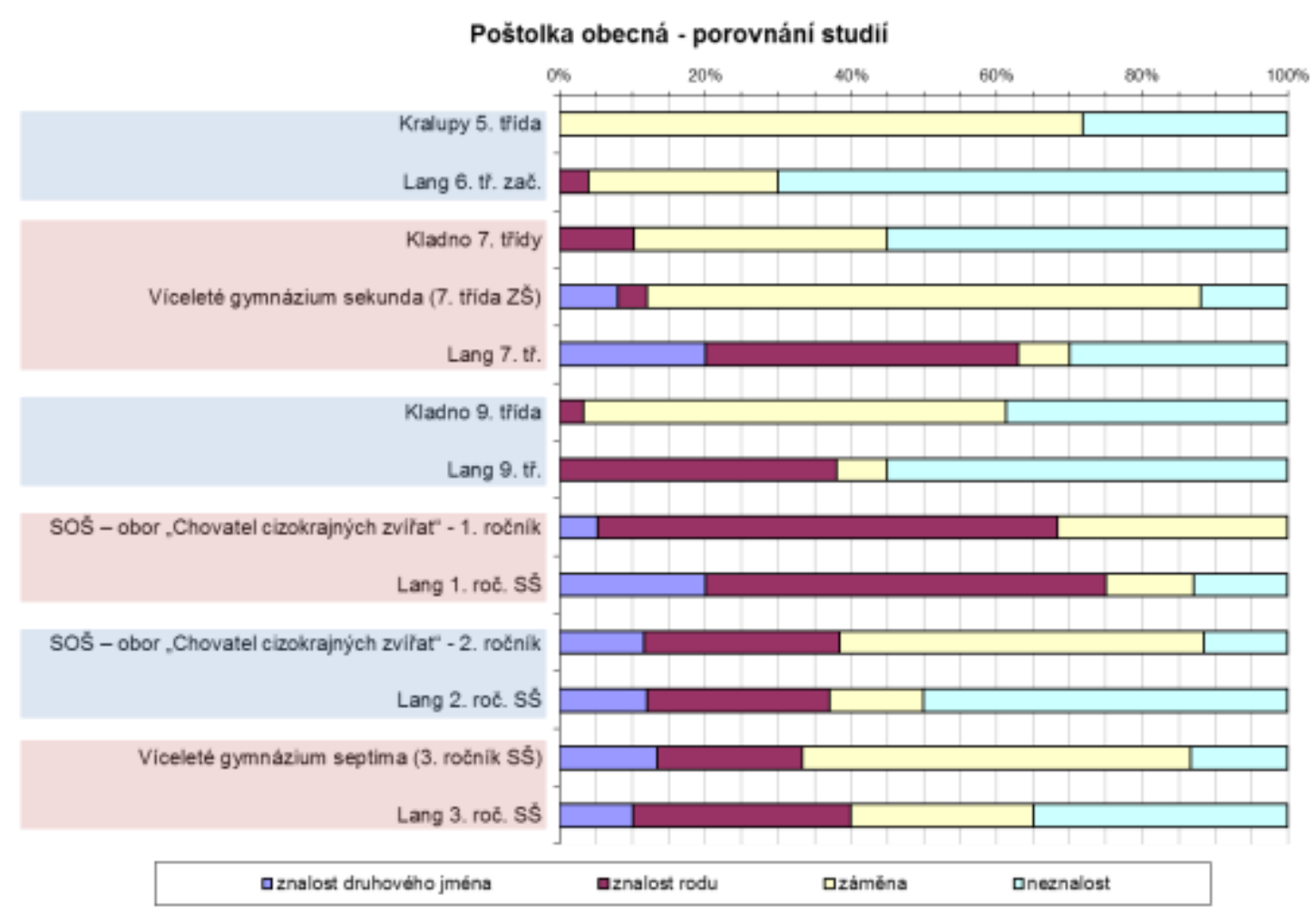

Graf 10 Porovnání znalosti druhu poštolka obecná pro jednotlivé věkové skupiny respondentů studie (Švecová, 2013) a studie (Lang, Pravda, 1971) 


\section{Pěnkava obecná (Fringilla coelebs)}

Téměř shodný výsledek měly porovnávané soubory pouze ve věkové skupině 9. tříd. Dotazovaným v obou těchto souborech ("Lang" a Kladno 9. tř.) se podařilo určit pouze rod pěnkava, a to jenom s úspěšností pohybující se okolo $15 \%$. Ve všech ostatních věkových skupinách byly úspěšnější soubory "Lang". Jejich respondenti dosahovali výsledků o 10 až $15 \%$ lepších než dotazovaní v souborech současných. Věkovou skupinou s nejzajímavějšími výsledky byly soubory 7. tříd. Zatímco soubor Kladno 7. tř. měl úspěšnost nulovou, v souboru "Lang" respondenti pěnkavu určili v 55\% případů. Soubor Gymnázium sekunda dosáhl necelých 45\% a zároveň byl nejúspěšnějším souborem v určení druhového jména (40\% dotazovaných v tomto souboru uvedlo správně celý název).

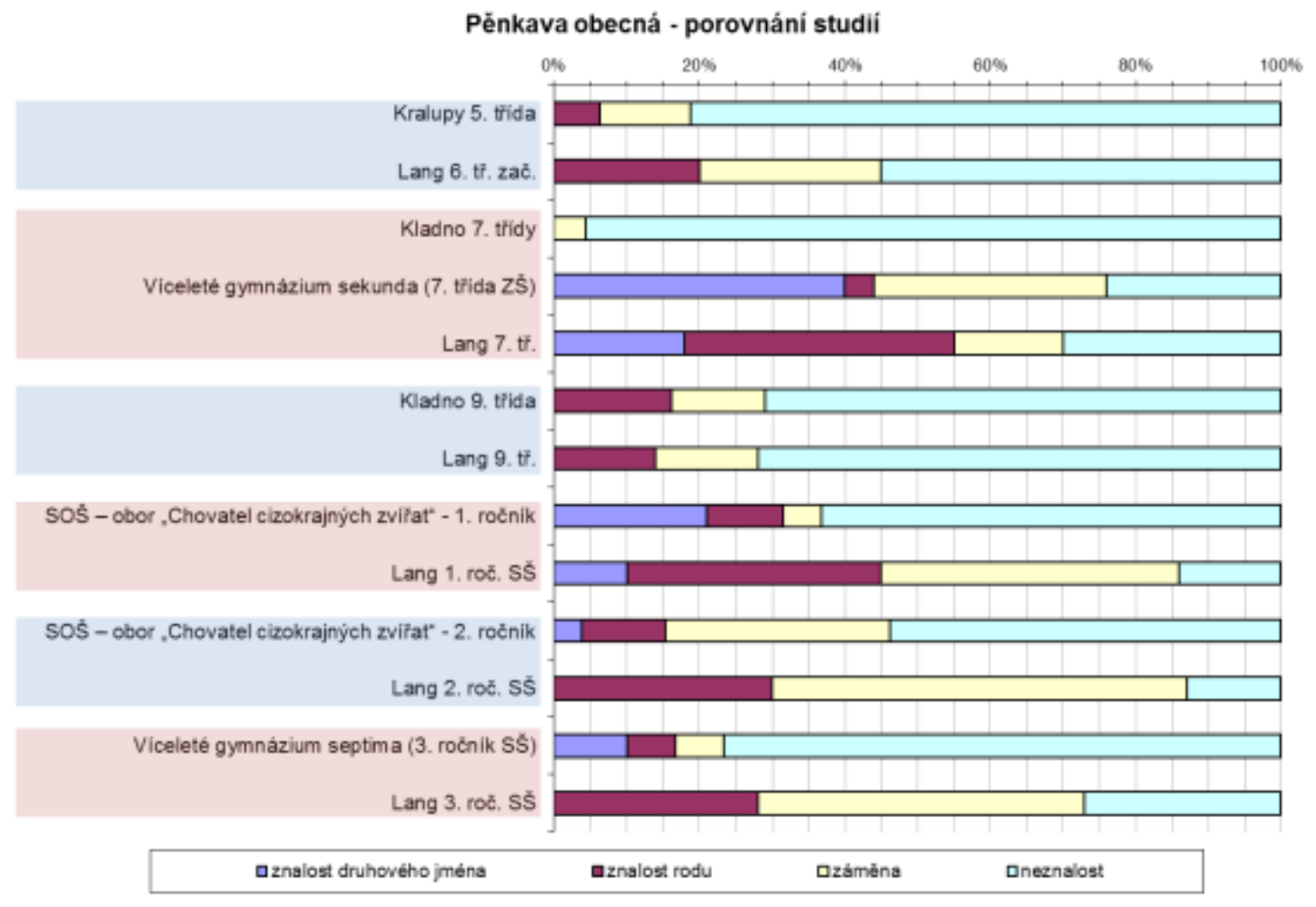

Graf 11 Porovnání znalosti druhu pěnkava obecná pro jednotlivé věkové skupiny respondentů studie (Švecová, 2013) a studie (Lang, Pravda, 1971)*** 


\section{Jiřrička obecná (Delichon urbica)}

Protože $v$ současných testovaných souborech se projevila v určování tohoto druhu velmi silně kategorie záměn ( $v$ souvislosti s taktéž zařazenou vlaštovkou obecnou), zaměřili jsme se na počty záměn i v souborech "Lang". Z výsledků studie (Lang, Pravda, 1971) není patrné, za které druhy tehdejší respondenti jiřičku nejčastěji zaměňovali a zda se př́padně také v tak vysokém počtu domnívali, že se jedná o vlaštovku. Z grafu je však žrejmé, že již tenkrát bylo nápadně vysoké procento odpovědí v kategorii záměn, procentuelně je tato kategorie dobře srovnatelná pro soubory „Lang" a soubory současné. Z porovnávaných věkových skupin pak byly ve třech př́padech úspěšnější soubory "Lang", jmenovitě se jednalo o věkové skupiny 9 . tříd, 1 . ročníků SŠ a 3. ročníků SŠ. V dalších třech věkových skupinách bylo naopak dosaženo lepších výsledků v souborech současných.

Určení druhového jména se nejlépe dařilo v souboru Gymnázium sekunda, kde správně odpovědělo celých $60 \%$ respondentů. Žádný další porovnávaný soubor se tomuto výsledku nepřiblížil, kategorie znalost druhového jména u nich dosáhla maximálně okolo $10 \%$.

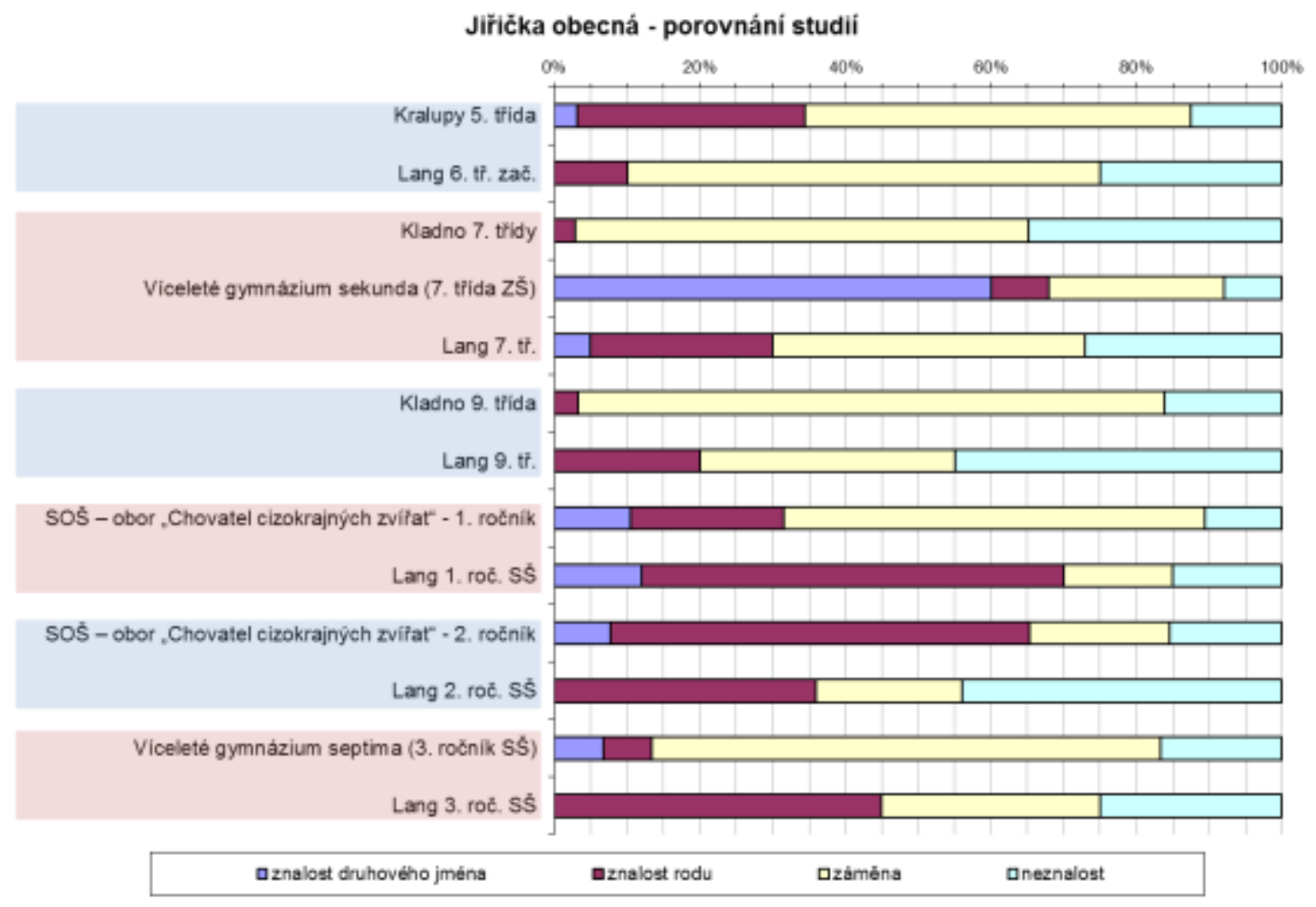

Graf 12 Porovnání znalosti druhu jiřička obecná pro jednotlivé věkové skupiny respondentů studie (Švecová, 2013) a studie (Lang, Pravda, 1971) 


\section{Krtek obecný (Talpa europaea)}

Všechny sledované soubory měly v určování tohoto savce vysokou úspěšnost (80 až $100 \%)$. Výsledky ve všech věkových skupinách byly obecně velmi vyrovnané, mírně lepších výsledků především v určování druhového jména bylo dosaženo v současných testovaných souborech.

Jedná se o známý a běžný druh, který byl velmi dobře určován všemi respondenty, kteří se zúčastnili výzkumu v současnosti i ve studii "Lang".

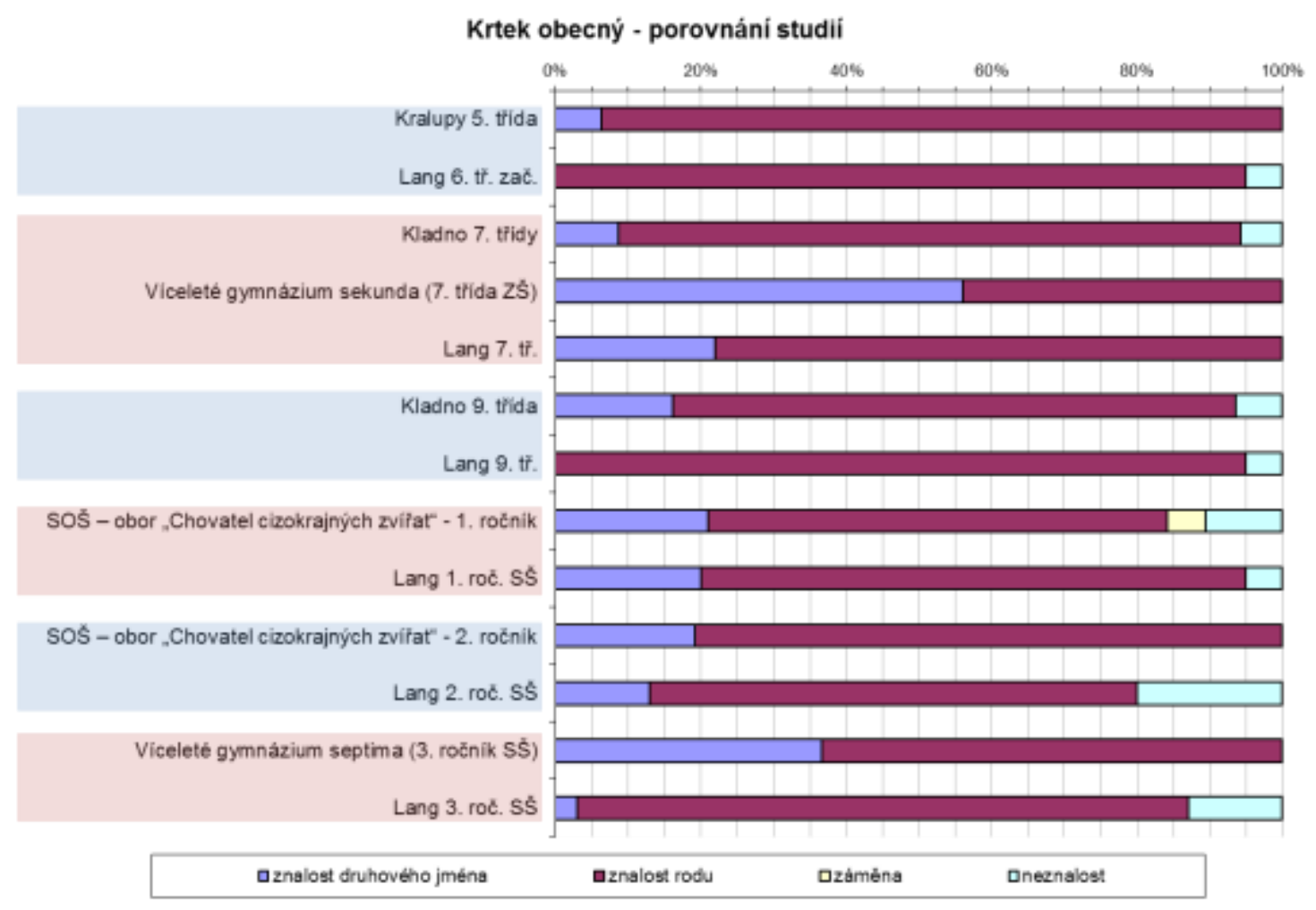

Graf 13 Porovnání znalosti druhu krtek obecný pro jednotlivé věkové skupiny respondentů studie (Švecová, 2013) a studie (Lang, Pravda, 1971)

\section{Diskuse k výsledkům srovnání studií}

Při porovnávání jednotlivých souborů se studií (Lang, Pravda, 1971) je třeba přihlédnout k faktu rozdílných vyučovacích osnov resp. školního vzdělávacího programu. Tato skutečnost může do značné míry ovlivnit výsledky, nebot' právě probíraná látka je v paměti "nejživější”. V důsledku zrušení jednotných školních osnov nelze zcela bezpečně určit, kdy se daná látka probírá a může tak dojít ke zkreslení nebo minimálně k posunu výsledků k jiné věkové skupině (třídě, ročníku). Tento problém by si zasloužil hlubší analýzu, která ale od počátku nebyla náplní předložené studie.

U většiny referenčních druhů dochází k překvapivé shodě výsledků současných testovaných souborů se studií (Lang, Pravda, 1971), přičemž odchylka je průměrně $10 \%$. Samozřejmě se vyskytují extrémy, zvláště pak v souborech SOŠ, kde Ize vzhledem k zájmu 
o obor předpokládat lepší znalost živočišných druhů než u "běžných středoškolákư" gymnazistů. Soubory SOŠ dosahovaly proto lepších výsledků u většiny srovnávaných druhů než věkově odpovídající skupiny ze studie (Lang, Pravda, 1971), kde se jednalo o žáky SVVŠ (gymnázií).

Stejně tak je z grafů patrné, že starší respondenti dosahují lepších výsledků než mladší. Je přirozené, že zájem některých dětí o přírodu se může prohlubovat s přibývajícím věkem. Tento jev se dá vysvětlit nejen vlivem výuky na školách.

Informace a znalosti mohou zájemci o přírodu získávat z nejrůznějších zdrojů. Samožrejmě zde hraje roli nejen internet a televize nebo dnes mládeží dost opomíjené knihy, ale velký význam má i „přenos" zájmu rodičů na své potomky. Jistě též podstatný vliv mají také osoby $v$ blízkém okolí (nejen učitelé a rodiče), které dokáží svou osobností a nadšením pro věc strhnout i nepř́liš přírodovědně zaměřené lidi.

\section{Závěr}

Hlavním cílem studie bylo provést výzkum a ověření úrovně biologických znalostí současných žáků ZŠ a SŠ v určování běžných druhů našich obratlovců, včetně porovnání se starší podobně orientovanou literaturou. Komparace byla provedena se studií (Lang, Pravda, 1971), která publikovala výsledky podobného výzkumu provedeného v roce 1970 . Existence jiné novější srovnatelné studie není autorům známa.

Volba ilustrace jako media zprostředkujícího možnost poznávání druhů a jejich určování nebyla náhodná, i když autorům bylo zřejmé, že určování podle vyobrazení je jen jedna $z$ možných hladin znalostí. Určování podle fotografií, filmů, jedinců $v$ chovu a pozorování v př́rodě jsou výrazně složitější úkoly, které zároveň vyžadují složitější objektivní vyhodnocení. Tyto otázky by se ovšem mohly stát předmětem zadání budoucího výzkumu.

Aby bylo možné objektivní srovnání se studií (Lang, Pravda, 1971), bylo nutné použít totožnou metodiku, a proto byly vybrány soubory $\mathrm{v}$ různých věkových skupinách (od 4 . tř́dy ZŠ po 4. ročník SŠ). Na těchto souborech bylo provedeno testování pomocí vyobrazení, která reflektují zřetelné diakritické znaky.

$\checkmark$ roce 1970 byl průzkum prováděn na velmi obsáhlém souboru respondentů (celkem jich bylo 6288) ve třech krajích, 3500 respondentů bylo žáky ZDŠ (základních devítiletých škol), 2788 respondentů navštěvovalo $v$ té době SVVŠ (tj. střední všeobecně vzdělávací školy - gymnázia).

Současná studie byla koncipována skromněji, zahrnovala výsledky od celkem 298 respondentů. Přesto Ize konstatovat, že konkrétní výsledky většiny souborů obou studií jsou vcelku srovnatelné. Nedošlo k výraznému posunu znalostí dnešních dětí k horšímu, jak bývá často prezentováno. Zároveň ovšem nedošlo ani k posunu pozitivním směrem.

Do současného průzkumu však byly zařazeny také soubory, které se vymykají celorepublikovému průměru (SOŠ - obor "Chovatel cizokrajných zviŕat" a př́rodovědně chovatelský kroužek ZOO Praha). Jejich výsledky byly podle očekávání výrazně lepší.

Pro další práci a výzkum by bylo žádoucí zaměřit se na skladbu učebnic, způsob vyučování biologie $v$ oblasti praktického poznávání jednotlivých organismů a zkoumání dalších vlivů. 
Jen málokde se prolínají environmentální a biologické aspekty tak výrazně, jako u výuky konkrétních druhů, jejich biologie a ekologie. Snaha o ochranu druhů, a vlastně i prosté dodržování platného zákona, který druhy chrání, se bez elementární znalosti a schopnosti determinace konkrétních druhů rozhodně nemůže obejít. Prastaré heslo otců zakladatelů ochrany prrírody, tedy Poznej a chraň, si jednoznačně podrželo svoji platnost.

\section{Literatura}

- ANDRESKA, J. Některé aspekty výuky zoologie obratlovců. Disertační práce, rukopis. Praha: Pedagogická fakulta, 2005.

- $\quad$ BALÁT, F. Klíč k určování našich ptáků v prírodě. Praha: Academia, 1986

- ČEĚKOVSKÝ, J.; ZÁVESKÝ, A. Stezky $k$ prírodě. Praha: Státní pedagogické nakladatelství, 1989. ISBN 80-04-22378-8

- ČIHAŘ, J. a kol. Př́roda v ČSSR. Praha: Práce, 1988

- KHOLOVÁ, H. Zoolog, odznak odbornosti. Praha: Mladá fronta, 1980

- $\quad$ LANG, J.; PRAVDA, O. a kol. Problematika praktických znalostí biologických objektů. Praha: SPN, 1971

- PECINA, P. Kapesní atlas chráněných a ohrožených živočichů, 1. díl. Praha: Státní pedagogické nakladatelství, n.p., 1988

- PELIKÁN, J.; GAISLER, J.; RÖDL, P. Naši savci. Praha: Academia, 1979

- $\quad$ PLESNÍK, J.; HANZAL, V.; BREJŠKOVÁ, L. [eds.] Červený seznam ohrožených druhů České republiky. Obratlovci. Praha: Př́roda 22, 2003. ISBN 80-86064-33-6

- POVOLNÝ, D. Hmyz - 3 znaky, klíč ke spolehlivému určování. Dobřejovice: Rebo Productions CZ, spol. s r. o., 2011. ISBN 978-80-255-0010-1

- S ŠVECOVÁ, K. Analýza úrovně znalostí běžných druhư našich obratlovců u dětí z různých typů škol a zájmových uskupení. Diplomová práce, rukopis. Praha: Pedagogická fakulta, 2013

\section{Použité právní předpisy}

1. zákon ČNR č. 114/1992 Sb., o ochraně přírody a krajiny, ve znění pozdějších předpisů

2. vyhláška MŽP č.395/1992, kterým se provádí zákon o ochraně přírody a krajiny, ve znění pozdějších předpisů 


\section{Obrazová příloha}

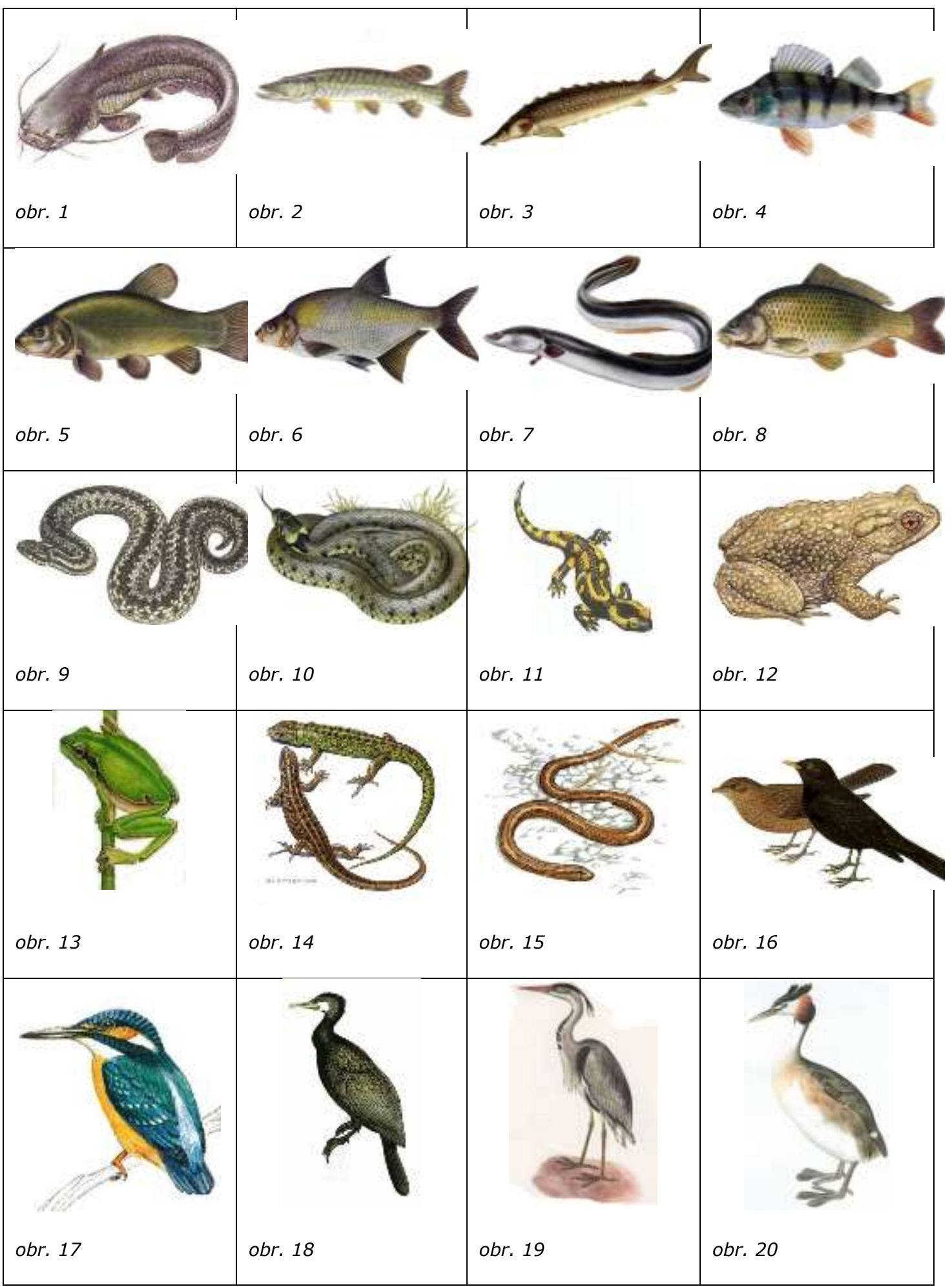




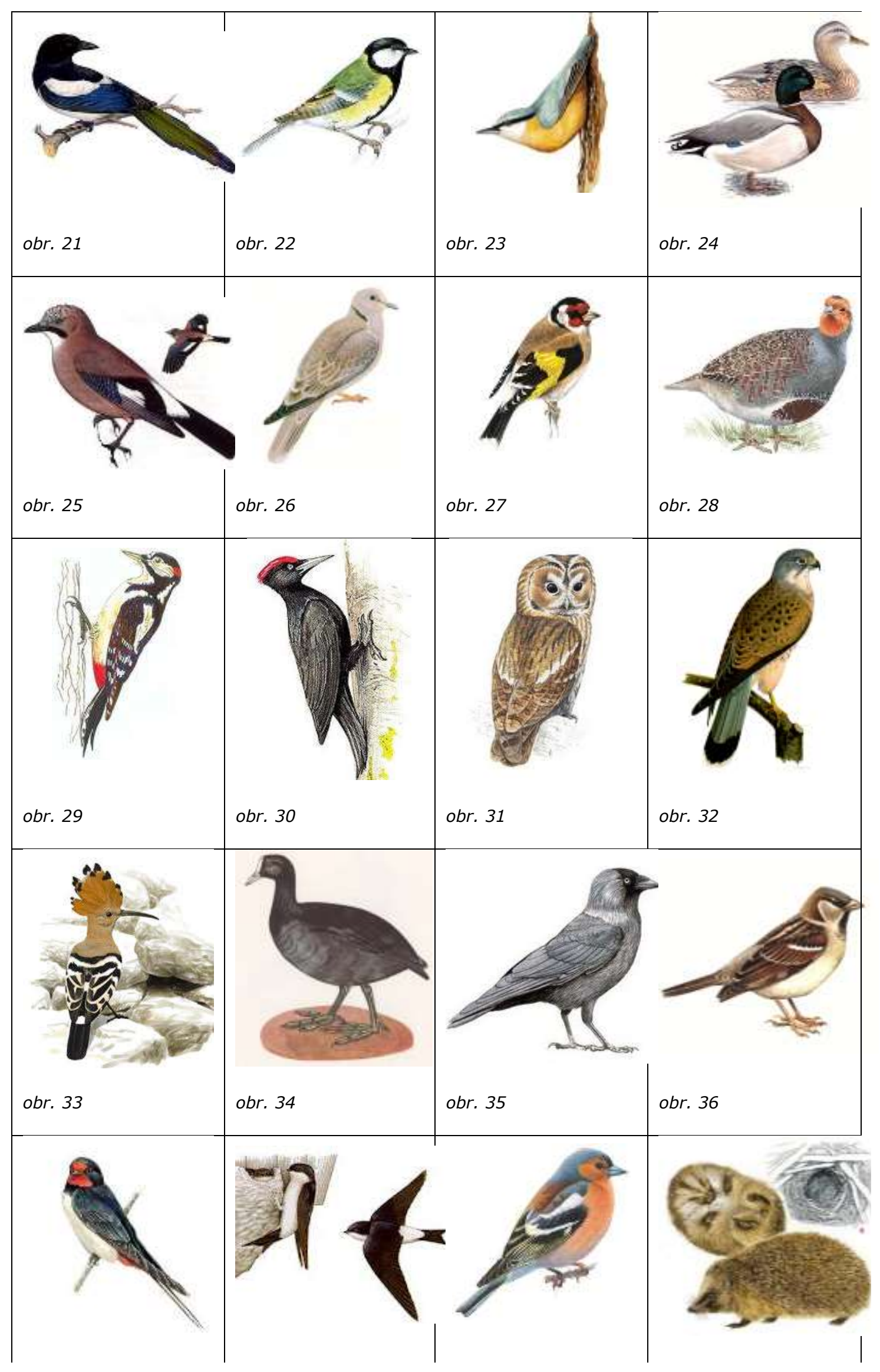




\begin{tabular}{|c|c|c|c|}
\hline obr. 37 & obr. 38 & obr. 39 & obr. 40 \\
\hline obr. 41 & obr. 42 & obr. 43 & $f_{4}$ \\
\hline obr. 45 & obr. 46 & obr. 47 & obr. 48 \\
\hline obr. 49 & obr. 50 & obr. 51 & obr. 52 \\
\hline
\end{tabular}

